SCJR 11, no. 1 (2016): 1-3

\title{
Carol Bakhos The Family of Abraham: \\ Jewish, Christian, and Muslim Interpretations
} (Cambridge, MA: Harvard University Press, 2014) ix + 285 pp.

\author{
MOSHE BLIDSTEIN \\ moshe.blidstein@mail.huji.ac.il \\ Hebrew University of Jerusalem, Jerusalem 9190501
}

Readers of Carol Bakhos' book, The Family of Abraham: Jewish, Christian, and Muslim Interpretations, may feel at times as if they are in a chamber of mirrors. The "family" in the title refers at first instance to the actual family of the biblical Abraham--Terah, Sarah, Hagar, Isaac and Ishmael — and to the parallel characters in Islamic traditions. These figures are the focus of the book. In parallel, it refers to the religions sometimes known as "Abrahamic"-Judaism, Christianity, and Islam. As Bakhos shows, these two types of "families" were in constant interaction. The mythical figures were shaped by centuries of interpretation by members of the three religions, and, in turn, the three religions and the relationships between them were conceptualized and imagined by reference to the figures. There was, therefore, a continuing reshaping of the role of Abraham and his family in each of the religions, and, moreover, of their roles as figures marking the ambiguous borders between the religions.

Many have written on Abraham, Sarah, Hagar, Isaac, and Ishmael, in the Bible and in subsequent traditions. Bakhos' book is, however, innovative in its focus on the whole family and on interactions between its members. This can be seen in the chapter outline. The first chapter of the book is a useful overview of the history of interpretation in each of the three traditions, mostly in the first millennium CE. Chapters two and three focus on Abraham himself, first as depicted in the Bible and the Quran and then as interpreted by subsequent traditions. Chapter four is dedicated to the confrontations between Hagar, Sarah, and Abraham, chapters five and six to Ishmael and Isaac, and chapter seven to the sacrifice of Isaac or Ishmael. The subject is also served well by the rigorous comparative framework: each chapter dedicates roughly equal space to each of the religious traditions, followed by discussion. The text is very readable, appealing to a wide audience, with the scholarly references confined to copious endnotes.

A point which emerges from all of the chapters is the divide between Judaism and Christianity, on the one hand, and Islam, on the other. For the former the text of the Hebrew Bible is canonical, while for the latter it is not, even if parts of the narrative filtered into Islamic tradition. While Abraham himself frequently 
features in the Quran, the rest of the family rarely does, and they become significant only in subsequent Islamic literature. Therefore, the story of Abraham's family is necessarily much more central to Jewish and Christian than to Islamic identity, and this could not but have a decisive influence on the history of interpretation.

The author shows that the historical arc of interpretation tended toward increasing demarcation and isolation of each of the religious traditions from the others. If at first there is room for all of the members of the family to be viewed as complex human beings with varying wishes and emotions, historical confrontations between the three religions led to a flattening of the characters amid attempts to claim them for each group. This trend was much stronger and earlier in Judaism and Christianity, however, than in Islam. Muslims were apparently less invested in the biblical narrative and less interested in laying absolute claims to its heroes.

Throughout the book, Bakhos underlines the problematic and simplistic nature of the term "Abrahamic," which she attributes mostly to naïve partners to inter-religious dialogue hoping to find easy common ground between Islam, Christianity, and Judaism. Since Abraham and his family were historically contested between the religions rather than providing space for agreement, Bakhos argues that using "Abrahamic" uncritically, as well as invoking the fraternal relations between the sons of Abraham, will not lead to greater understanding or to better relations between the adherents of the modern religions. Nevertheless, she claims that comparative analysis of the textual traditions of these religions, whether conducted under such terms such as "Abrahamic" or other terms, is essential for their understanding.

As Bakhos recognizes, Abraham and his family are not the most important figures in these three religions; Jesus, Muhammad, and Moses receive that honor. Abraham's significance is that he is conceived as the forerunner, precursor, or forefather of the religious communities. As such he is apriori not-quite-there yet, a potential and not actual Christian, Muslim, or Jew. This may be the reason that Abraham has the potential to be an inclusive symbol, signaling a moment when the borders were still porous, or at least somewhat so. Though this image was chipped away at during centuries of interpretation, the traditions could return to it when a more open stance towards the other religions was desirable.

The author opposes invoking Isaac and Ishmael as siblings in order to encode a natural closeness between Arabs and Jews, and is also opposed to a similar reading of the relationship between Sarah and Hagar. Such political readings are dangerous, she argues, as they rely on the traditional identification of Arabs with Ishmael and Jews with Isaac, and thus come with the baggage of the superiority of the latter over the former in Jewish and Christian literature. As an alternative, Bakhos prefers a psychological-emotional reading which acknowledges feelings of jealousy and fear (especially Sarah's) as a driving force behind these stories. Such a psychological reading turns the story into a universal human narrative, which is probably easier for most practitioners of interreligious dialogue in the West to relate to than a starkly political reading. Bakhos demonstrates that it may 
also be a more literal reading of the biblical text than subsequent interpretation. However, I am not sure that simply returning to the biblical text while shedding a millennium of socio-political reception is possible for many members of the respective communities, or that this is a strategy that should be promoted. Perhaps a story of a family in murderous strife, rather than individuals under emotional strain, is indeed closer to reality in the Middle East, and it is this aspect of the story that may reverberate.

Bakhos' book is an engaging and persuasive study of exegesis in the Abrahamic religions and especially of the fate of biblical characters. It demonstrates that despite the rich variety within each tradition, the historical context and starting-point of each tradition strongly determined the dominant mode of interpretation. 